\title{
Radula morphology of Clione limacina (Phipps, 1774) (Gastropoda: Heterobranchia: Gymnosomata)
}

\author{
E.V. Vortsepneva \\ Department of Invertebrate Zoology, Biological faculty, Moscow State University, Leninskie gory \\ 1/12, 119234 Moscow, Russia. \\ E-mail: vortcepneva@gmail.com
}

\begin{abstract}
The radula of gastropods is a unique structure of the feeding apparatus, which is characterized by its incredible morphological diversity. The radula consists of the teeth attached to the radular membrane and is formed by specialized cells in the radular sac. The mode of the radula formation, including the type of secretion, the number, size, and shape of the cells forming one tooth, can vary significantly between different mollusks. Clarification of this diversity is the key to determining the patterns of radula formation in Gastropoda. The general morphology and ultrastructure of radula of Clione limacina (Gastropoda: Pteropoda) was studied using light, electron, and confocal laser scanning microscopy for the first time. The radula formula is $n-1-n$ with wide central tooth and hooklike lateral teeth (from 7 to 12). The unique feature for the Gymnosomata is the increasing size and number of teeth during the life of the animal, possibly, due to the unique position of odontoblasts, located on the periphery of the blind end of the radular sac. The ultrastructure of $C$. limacina combines features and characteristics that are typical for all Heterobranchia. Ultrastructure of the formation zone (cells in the formation zone with poor differentiation), structure of radular membrane, and absence of subradular membrane are characteristic for C. limacina. The mode of tooth formation (one tooth is formed by several odontoblasts and microvillar secretion), radular bolsters, and muscular morphology are similar to other Heterobranchia. The firm connection between radula and radular bolster without a subradular membrane, the muscular radular support structure, which gives additional mobility to the radula, and muscles which connect hook sacs could indicate a significant contribution of the radula to scraping the prey. As a result of this study, the ultrastructure of the radular apparatus of one species Gymnosomata was described for the first time. These data significantly extend our knowledge of the gastropod's radula formation.

How to cite this article: Vortsepneva E.V. 2020. Radula morphology of Clione limacina (Phipps, 1774) (Gastropoda: Heterobranchia: Gymnosomata)// Invert. Zool. Vol.17. No.3. P.291-309. doi: 10.15298/invertzool.17.3.06
\end{abstract}

KEY WORDS: ultrastructure, chitin, radular formation, odontoblasts, Pteropoda. 


\section{Общая морфология и ультратонкое строение радулы Clione limacina (Phipps, 1774) (Gastropoda: Heterobranchia: Gymnosomata)}

\section{Е.В. Ворцепнева}

Кафедра зоологии беспозвоночных, биологический факультет, МГУ имени М.В.Ломоносова, Ленинские горы 1/12, Москва, 119234, Россия.

E-mail: vortcepneva@gmail.com

РЕЗЮМЕ: Радула брюхоногих моллюсков — это уникальная структура пищедобывательного аппарата, отличающаяся невероятным морфологическим разнообразием. Радула состоит из радулярной мембраны и прикрепленных к ней зубов. Формирование радулы происходит в радулярном мешке специализированными клетками. Способ формирования радулы, включая тип секреции, количество, размер и форма клеток, образующих один зуб, может существенно различаться у разных моллюсков. Выяснение этого разнообразия является ключом для определения основных паттернов формирования радулы у Gastropoda. Впервые была изучена общая морфология и ультратонкое строение радулы Clione limacina (Gastropoda: Pteropoda) с использованием световой, электронной и сканирующей лазерной конфокальной микроскопии. Радула $C$. limacina c формулой n-1-n, несет широкую центральную пластинку и крючковидные латеральные зубы (от 7 до 12). Уникальной особенностью радулы представителей Gymnosomata является увеличение количества зубов в течение жизни одной особи, что, вероятно, может быть обусловлено положением одонтобластов по периферии в зоне формирования радулы. Ультратонкое строение радулы $C$. limacina сочетает в себе особенности, характерные для всей группы гетеробранхий, такие как малоклеточное формирование зуба и микровиллярная секреция, строение мышечных валиков одонтофора и строение мускулатуры радулярного аппарата, так и уникальные особенности, такие как, плохо выраженная дифференцировка одонтои мембранобластов, ультраструктура радулярной мембраны и отсутствие субрадулярной мембраны. Прочный контакт между радулой и мышечным валиком одонтофора без субрадулярной мембраны, строение мышечного валика, который придает радуле дополнительную подвижность, и мышцы, которые соединяют радулу и мешки крючьев, могут указывать на значительный вклад радулы в выскабливание добычи. В результате этого исследования впервые было описано ультратонкое строение радулярного аппарата одного вида Gymnosomata, что дополняет картину разнообразия формирования радулы брюхоногих моллюсков.

Как цитировать эту статью: Vortsepneva E.V. 2020. Radula morphology of Clione limacina (Phipps, 1774) (Gastropoda: Heterobranchia: Gymnosomata) // Invert. Zool. Vol.17. No.2. P.291-309. doi: 10.15298/invertzool.17.3.06

КЛЮЧЕВЫЕ СЛОВА: ультраструктура, хитин, формирование радулы, одонтобласты, Pteropoda. 


\section{Introduction}

Gymnosomata is a group of holoplanktonic carnivorous shell-less pteropods with modified parapodia, or outgrowths of the side of the foot (wing-like appendages) for the active swimming. From 41 to 69 species of Gymnosomata have been recorded (Lalli, Gilmer, 1989; Pruvot-Fol, 1954; van der Spoel, 1976). One of the best-studied species is Clione limacina (Phipps, 1774). Anatomy of C. limacina (Morton, 1958; Lalli, 1970; Huang, Satterlie, 1989; Hermans, Satterlie, 1992; Vortsepneva, Tzetlin, 2014), biology and ecology (Conover, Lalli, 1974; Hopkins, 1985; Kattner et al., 1998; Yamazaki, Kuwahara, 2017; Yamazaki et al., 2018), physiology (Arshavsky et al., 1989; Arshavsky et al., 1990; Satterlie, 1991; Norekian, Satterlie, 1997; Norekian et al., 2019), and phylogeny (Thollesson, 1999; Klussmann-Kolb, Dinapoli, 2006; Dinapoli, Klussmann-Kolb, 2010; Corse et al., 2013; Zapata et al., 2014) have been well studied.

Clione limacine is monophagous and feeds exclusively on other pteropod, Limacina helicina (Phipps, 1774). The hunting apparatus of $C$. limacina consists of three pairs of buccal cones (cephaloconi) with sticky glands, two hook sacs, and a small radula. Buccal cones are elongating during retraction but become more cylindrical when extruded. Contact with a victim is required for C. limacina to begin feeding. At this moment, buccal cones are quickly ejected from the buccal cavity and hold the victim for up to several hours. After $C$. limacina catches the prey, it scrapes the soft body using hooks and radula (Hermans, Satterlie, 1992; Lalli, 1970; Morton, 1958).

Each hook sac opens with a small hole to the buccal cavity. During feeding, the muscular apparatus extends the hooks from the sac (Lalli, 1970). About 30 chitinous hooks are arranged in irregular rows on the medial side of the sac and gradually increase in size in the direction from the top to the base of the hook sac. The smallest hooks locate closer to the opening of the sac; the largest hooks are at the bottom of the sac (Morton, 1958; Lalli, 1970). At the ultrastructural level, each hook contains a big cell (gnatho- blast), which is covered by a thin electron-dense matrix (Vortsepneva, Tzetlin, 2014). The muscles of the hook sac are well developed: longitudinal ones form the internal layer, and circular ones are situated outside (Morton, 1958). Hook sacs are connected to the radula and each other at the base by the ventral transverse musculature. Radular apparatus is located between the hook sacs and consists of chitinous ribbon, pair of radular bolsters and radular musculature. Radular formula is $n-1-n$ with wide central tooth and several hook-like lateral teeth (Pruvot-Fol, 1954; van der Spoel, 1976). The protrusion of the radula working zone is provided by oblique protractor muscles running antero-ventrally from the anterior part of the radula to each hook sac. The radula unfolds in the working zone due to the subradular membrane being pulled and stretched over the bending plane by a retractor muscle. This muscle, attached to the radular sac in the posterior end, extends longitudinally through the sac, branches, and connects to the radula in the working zone. Haemocoel pressure within the buccal mass is probably essential in radular movements (Lalli, 1970).

Despite the fact that radular morphology is one of the taxonomically significant characters in Gastropoda, only general morphology studies were done for Clione limacina. Since the fine morphology of a radula is important for the identification of general patterns of hard pharyngeal structures (jaws and radula) formation, the current study is dedicated to the first description of the ultrastructure of C. limacina radula.

\section{Materials and methods}

During June of 2009-2010 and 2019, 13 specimens of Clione limacina were sampled by a plankton net from the pelagic zone in the environs of the Pertsov White Sea Biological Station of Moscow State University in the Kandalaksha Bay, the White Sea, Russia $\left(66^{\circ} 33^{\prime} \mathrm{N}\right.$, $\left.33^{\circ} 06^{\prime} \mathrm{E}\right)$. The phographs of live relaxed specimens have been taken with stereomicroscope MBS-10 by iPhone 5C camera with additional adapter iDu Optics LabCam Microscope. 
General morphology and ultrastructure

For morphological studies, specimens were relaxed in an isotonic $\mathrm{MgCl}_{2}$ solution (5\%) prior to fixation and then fixed. A total of thirteen specimens of $C$. limacina were fixed: four specimens for general morphology studies by scanning electron microscopy (SEM) and six specimens (three dissected anterior ends and three dissected buccal complexes) for the histological and ultrastructural studies. Three dissected radulae were studied by confocal laser scanning microscopy.

For SEM, histological and ultrastructural studies all specimens were fixed in $2.5 \%$ glutaraldehyde in $0.1 \mathrm{M}$ phosphate buffer ( $\mathrm{pH} 7.2-$ 7.4) for 3 hours at $4{ }^{\circ} \mathrm{C}$. After the fixation, specimens for SEM studies were rinsed three times in $0.1 \mathrm{M}$ phosphate buffer for 2 hours, and then dehydrated in a graded ethanol series. Anterior ends of the specimens have been cut longitudinally through the buccal mass in $70 \%$ ethanol. Then the specimens were transferred from $70 \%$ ethanol by increasing concentration to acetone (30 minutes in each solution), critical point dried, sputter coated with platinum-palladium and gold, and observed under Hitachi S405 A and 400A scanning electron microscopes.

After fixation, specimens for histological and ultrastructural studies were rinsed in $0.1 \mathrm{M}$ phosphate buffer three times for 1.5 hours, postfixed in $1 \%$ osmium tetroxide on the same buffer for 2 hours in the darkness, then dehydrated in a graded ethanol series (30 minutes in each solution), transferred to acetone and embedded in Spurr resin, according to the manufacturer's instructions. Two transversal and one longitudinal series of semi-thin sections of the anterior end were made to investigate the general morphology of the buccal complex, and three transversal ultrathin series of the buccal complex were made for the ultrastructural studies. Dupont MT 5000 and Leica EM UC6 ultramicrotomes were used for sectioning. Semi-thin sections were stained with $1 \%$ toluidine blue and $1 \%$ methylene blue on $1 \%$ sodium tetraborate. All ultrathin sections were stained with $1 \%$ uranyl acetate for $40 \mathrm{~min}$ at $35^{\circ} \mathrm{C}$, followed by $0.4 \%$ lead citrate for $10 \mathrm{~min}$ at room tempera- ture. Ultrathin sections were examined using a Jeol JEM 1011 transmission electron microscope. Three-dimensional (3D) reconstructions were made from a series of semi-thin sections, as described by Ruthensteiner and $\mathrm{He} ß(\mathrm{Ru}-$ thensteiner, $\mathrm{He} \beta, 2008)$. Image stacks were aligned using AMIRA 5.2.2, and the radular sacs were reconstructed using Imaris 7.2.1.

\section{Chemical composition of the radula}

Three dissected radular sacs were fixed with a $4 \%$ paraformaldehyde solution on $0.1 \mathrm{M}$ phosphate buffer for $4-12$ hours at $4{ }^{\circ} \mathrm{C}$ with constant agitation. After fixation, specimens were washed three times by $0.1 \mathrm{M}$ PBS for 3 hours with constant agitation. After rinsing, radular sacs were stained by calcofluor white (Fluorescent Brightener 28, Sigma F3543) accordingly to the protocols described in several papers (Connors et al., 2012; Hickey et al., 2004 ) in $0.1 \mathrm{M}$ PBS for 1 hour at $4^{\circ} \mathrm{C}$ with constant agitation. After staining, specimens were washed three times by $0.1 \mathrm{M}$ PBS for 20 minutes and transferred into a drop of glycerol under cover glasses. The preparations were examined using an epifluorescent microscope (Leica DM2500) with filter set ext. 340-380 nm confocal laser scanning microscope Nikon A1.

\section{Results}

\section{General morphology of the buccal appa- ratus}

The buccal apparatus consists of three pairs of buccal cones, pair of hook sacs, and radular apparatus. In the relaxed condition, three pairs of buccal cones are elongated. Hook sacs and radular apparatus could evert out of the buccal cavity (Fig. 1A-B). The small radula is located between hook sacs (Fig. 1B-C). The mouth is slit-like (Fig. 1C). In the retracted condition, cones are significantly contracted, and hook sacs are located on the lateral sides of the esophagus (Fig. 1D-E). The esophagus is flattened on the sides. The radula is located in the ventral invagination of the buccal cavity (radular sac) (Fig. 1 E) and consists of the formation, maturation, working, and degradation zones (Fig. 2A-C). 

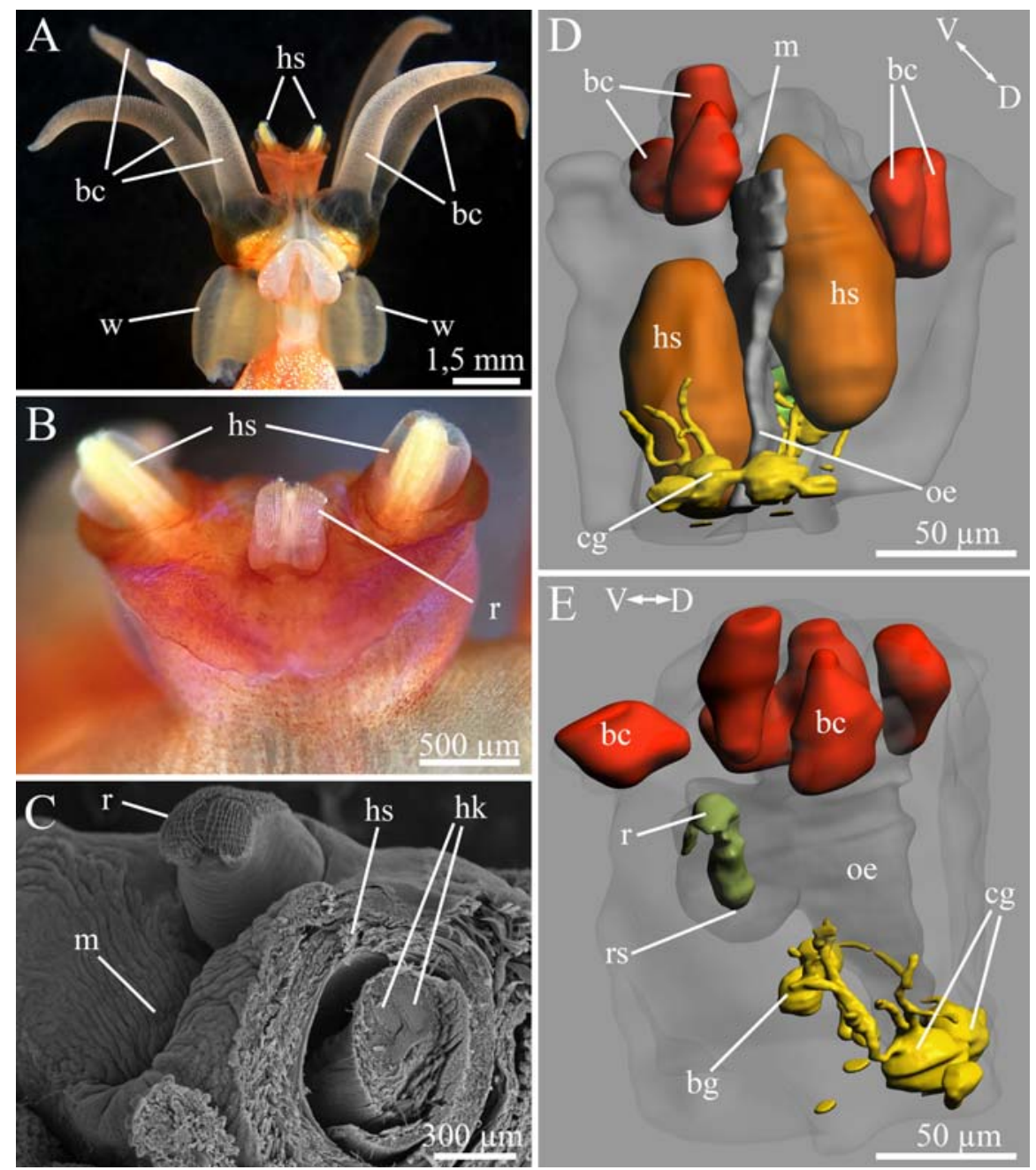

Fig. 1. General morphology of the buccal apparatus of Clione limacina. A - relaxed specimen with buccal organs protruded from the head. The buccal cones elongated, light microscopy photo; B - frontal view of the radula and hook sacs, light microscopy photo; C - lateral view of the radula and mouth. One hook sac is deleted, photo SEM; D - 3D reconstruction of the contracted buccal apparatus, dorsal view. The body wall is in semitransparent gray, red buccal cones are contracted; orange pair of the hook sacs located on the lateral sides of the esophagus; $\mathrm{E}-3 \mathrm{D}$ reconstruction of the contracted buccal apparatus, lateral view. The body wall and esophagus are semitransparent, green radula is located in the ventral invagination of the buccal cavity. Abbreviations: bc — buccal cone; bg — buccal ganglia; cg — cerebral ganglia; D — dorsal side; hk — hooks; hs hook sac; $\mathrm{m}$ - mouth; oe — esophagus; $\mathrm{r}$ - radula; $\mathrm{rs}$ - radular sac; $\mathrm{V}$ - ventral side; $\mathrm{w}$ - wing.

Рис. 1. Общая морфология буккального аппарата Clione limacina. A - буккальный комплекс расслабленной особи. Буккальные конусы вытягиваются, мешки крючьев и радула выдвигаются за пределы ротовой полости. Фото, световая микроскопия; В - фронтальный вид на радулу и радулярный мешок. Фото, световой микроскоп; С - радула и щелевидное ротовое отверстие, вид сбоку. Один мешок крючьев удален. Фото, сканирующий электронный микроскоп; D - трехмерная реконструкция переднего конца, буккальные конусы сокращены, мешки крючьев втянуты, вид с дорсальной стороны. Стенка тела серая полупрозрачная; Е - трехмерная реконструкция переднего конца, вид сбоку. Стенки тела и пищевода полупрозрачные, радула располагается в вентральном мешке.

Обозначения: bc - буккальный конус; bg - буккальный ганглий; $\mathrm{cg}$ — церебральный ганглий; D — дорсальная сторона; hk — крючья; hs — мешок крючьев; $\mathrm{m}$ - рот; ое — пищевод; r — радула; rs — радулярный мешок; V вентральная сторона; $\mathrm{w}$ - крыло. 

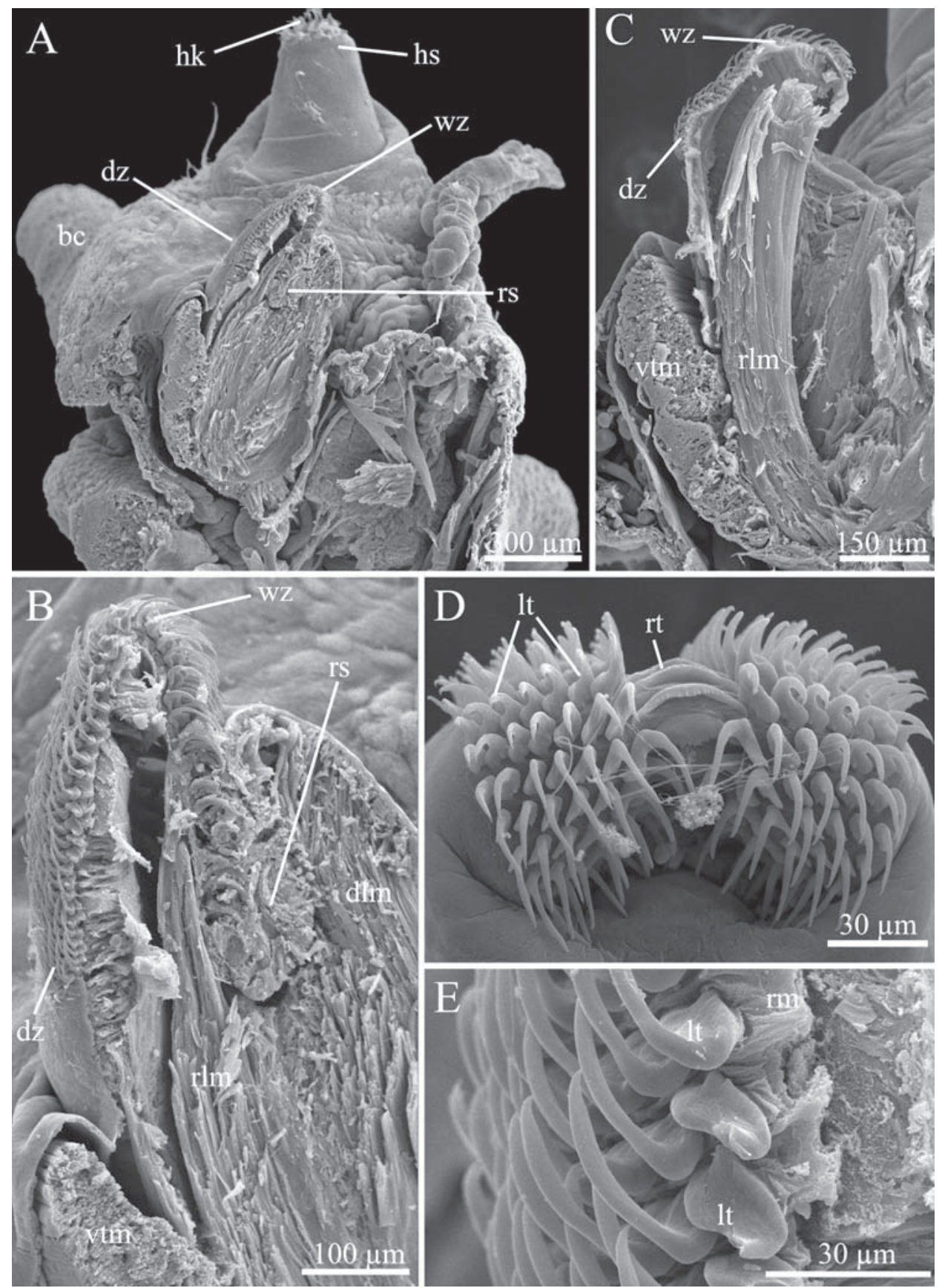

Fig. 2. Morphology of the radular apparatus of Clione limacina, photo SEM. A - lateral view of the half of the head with one hook sac. The radula has been dissected longitudinally; B - the radula in high magnification, the same specimens as in the photo A. Radular sac is surrounded by the muscles; C longitudinal section though the radula, the other half of the radula on the photo $\mathrm{B}$. The radular longitudinal muscles are attached to the working zone of the radula; D - general morphology of the radula in the working zone. One transversal row consists of the central plate and hooked lateral teeth; E - lateral view of the lateral teeth in the working zone. Radular membrane is thin, subradular membrane is absent. 
The radular apparatus consists of the radular ribbon, two bolsters of the odontophore, and muscles. The radula contains dentate rachidial tooth (central plate) and 7-12 hook-like lateral teeth (Fig. 2A, D-E). The number of lateral teeth depends on the specimen's size. The size of the teeth increases during maturation: based on the SEM photo in a single specimen the height of the matured teeth in the degradation zone (the oldest teeth) is $19-21 \mu \mathrm{m}$, while in the working zone it is $40-45 \mu \mathrm{m}$ (Fig. 2C, D). Radular teeth are forming in the formation zone. No mineralization zone has been identified, and therefore the term "maturation zone" is used for the zone where teeth increase in size and hardness. The working zone is located in the free end of the radula without concomitant epithelium. The radula is unfolded in the working zone and rolled in the radular sac (Fig. 3A-D; 4A-D). The degradation zone is located after the working zone (Fig. 2C). From three to four newest teeth rows were identified by calcofluor white staining. In the next three rows, only lateral teeth were marked by calcofluor white staining (Fig. $5 \mathrm{~A}-\mathrm{C})$.

A pair of the elongated radular bolsters underlay the radula (Fig. 3E-F; 4A-B). They consist of the longitudinal and transversal myocytes alternating with each other (Fig. 4A). Paired longitudinal radula muscles (retractors) are located under the radular sac, attached to the subradular epithelium in the working zone, and runs backward to the muscles at the bases of the hook sac (Fig. 2B, C; 3D-E). More developed longitudinal muscles are located above the rad- ular sac. The transversal musculature (ventral approximator muscles) connects the bases of the radular bolsters under the radular sac. Thick transversal muscles underlay the radular apparatus and are connected with the hook sacs (Fig. 3E-F; 4B-C).

\section{Ultrastructure of radular teeth and mem- brane}

The formation zone of the radula is located at the blind end of the radular sac. Teeth are in the inner perimeters of the radular sac (Fig. 4D; 6A). At the base, the newly formed tooth is penetrated by numerous microvilli and is uniformly electron-dense in the middle and top parts (Fig. 6B-E; 7A). The width of the tooth base of the studied specimens is $3-4 \mu \mathrm{m}$. The mature teeth are electron-dense with numerous granules; the base width is $6-7 \mu \mathrm{m}$ (Fig. 7C-D; $8 ; 9)$. The radular membrane is electron-dense and very thin in the formation zone $(0.2-0.5$ $\mu \mathrm{m})$ (Fig. 6C-D). In the maturation zone, the radular membrane consists of the transversal fibers, and its thickness is about $0.6-0.7 \mu \mathrm{m}$ (Fig. 7C-D; 8). In the working and degradation zones, the radular membrane is electron-transparent (Fig. 9) and thicker than in maturation zone (up to $1.2-1.3 \mu \mathrm{m}$ ). The subradular membrane is not developed in the working zone (Fig. 10A).

\section{Ultrastructure of odontoblasts and mem- branoblasts}

There are no visible differences in ultrastructure between odonto- and membranoblasts.

\footnotetext{
Abbreviations: bc — buccal cone; dlm — dorsal longitudinal muscles; dz — degradation zone of the radula; hk — hooks; hs — hook sac; $1 \mathrm{t}$ — lateral teeth; $\mathrm{r}$ — radula; rlm — radular longitudinal muscles (retractors); rm — radular membrane; rs — radular sac; $\mathrm{rt}$ - rachidial tooth; wz — working zone of the radula.

Рис. 2. Морфология радулярного аппарата Clione limacina. Фото, сканирующий электронный микроскоп. А - вид сбоку на половину головы с одним мешком крючьев. Радула срезана в продольном направлении; Б - радула особи на фото А на большем увеличении. Радулярный мешок окружен мускулатурой; C — продольный срез через радулу, вторая половина от радулы на фото В. Радулярные продольные мышцы прикреплены к рабочей зоне радулы; D - общая морфология радулы в рабочей зоне. Один поперечный ряд состоит из центральной пластины и крючковидных латеральных зубов; Е - вид сбоку на латеральные зубы в рабочей зоне. Радулярная мембрана тонкая, субрадулярная мембрана отсутствует.

Обозначения: bc - буккальный конус; dlm — дорсальная продольная мускулатура; dz — зона дегродации радулы; hk - крючья; hs — мешок крючьев; lt — латеральные зубы; r — радула; rlm — радулярная продольная мускулатура (ретракторы); rm — радуларная мембрана; rs — радулярный мешок; rt — центральный зуб; wz — рабочая зона радулы.
} 


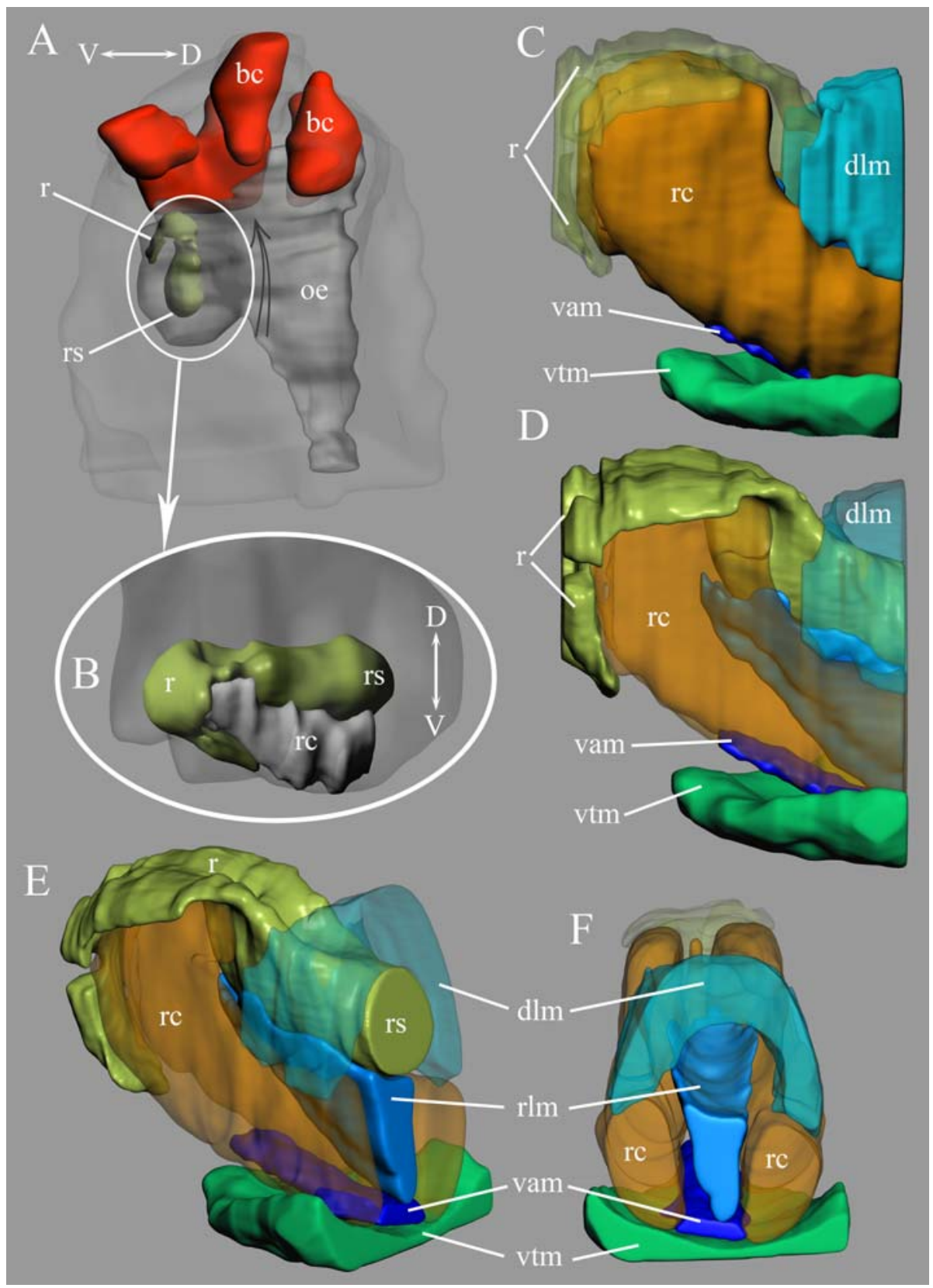

Fig. 3. Three-dimensional (3D) reconstruction of the radular complex of Clione limacina. A - general view of the head with radula and buccal cones; B - radular apparatus has been rotated on $90^{\circ}$ counterclockwise as in the reconstructions $\mathrm{C}-\mathrm{F}$; C - lateral view of the anterior part of the radular apparatus, the radula is semitransparent green, bolsters of odontophore are brown, muscles are green and blue; D - lateral view of the radular apparatus, bolsters of odontophore are brown semitransparent, transversal upper muscles are blue semitransparent. The radular retractors are located under the radular sac; E - radular apparatus, lateral view. Transversal ventral muscles (ventral approximator muscles) connect the bolsters in the base and dorsal muscles above the radular sac; F — back view of the radular apparatus without radular sac. 
Both cell types are square or rectangular (width up to $6.5 \mu \mathrm{m}$ and height up to $11.5 \mu \mathrm{m}$ ) and line the perimeter of the blind end of the radular sac. A single tooth is formed by several odontoblasts (Fig. 6C-D). The odontoblasts have electrontransparent cytoplasm with rough endoplasmic reticulum, mitochondria, and vacuoles (Fig. 7AB). Big oval nucleus (up to 3.2-7.9 $\mu \mathrm{m}$ ) locates at the base of the cell (Fig. 6A-C). The connections between cells are provided adherens junctions. The apical part of the odontoblasts bears numerous microvilli, penetrating the tooth base (Fig. 6B-E). The basal membrane is electrondense; its thickness reaches $0.15 \mu \mathrm{m}$ (Fig. 6C). The odontoblasts are alternated with cells of similar size, but with an electron-dense cytoplasm, containing electron-dense vesicles, possibly indicating apoptotic processes (Fig. 6C$\mathrm{D}$, asterisks).

\section{Ultrastructure of radular epithelium}

The main features of the concomitant epithelium of Clione limacina are the small number and comparatively large size of the cells. The cells of the subradular epithelium are similar in size and shape with the odontoblasts. Subradular epithelium consists of square or rectangular (up to $8.7 \mu \mathrm{m}$ in width and $13 \mu \mathrm{m}$ in height) cells with big oval $(4.1 \times 8.1 \mu \mathrm{m})$ nucleus in the base or center of the cells (Fig. 7C-D; 8). The cells are connected by adherens junctions in their apical parts. The basal membrane is thin (up to $0.15 \mu \mathrm{m}$ ) and electron-dense. The tonofilaments extend from the basal to the apical part of the cells (Fig. 8B). The contacts between cells of subradular epithelium in the working zone are stronger than in the other zones and have adherens junctions and cytoplasmic interdigitations; the cytoplasm contains bundles of tonofilaments (Fig. 9). The supraradular epithelium is located between the teeth (Fig. 8B). The cytoplasm of supraradular epithelium is electron-transparent with mitochondria, rough endoplasmic reticulum, Golgi apparatus, and vacuoles. Large oval nucleus is located at the base of the cell (Fig. $4 \mathrm{C}-\mathrm{D} ; 6 \mathrm{~A} ; 7 \mathrm{C})$. The buccal epithelium after the degradation zone is flattened with thin (0.6$0.65 \mu \mathrm{m}$ ) amorphous cuticle; the cytoplasm is electron-transparent. The connections between cells are provided by adherens junctions and septate junctions (Fig. 10D).

\section{Ultrastructure of radular bolster}

The radular bolsters contains the transversal and longitudinal muscles which are perpendicular to each other and consist of bundles 8.6$11.7 \mu \mathrm{m}$ in diameter (Fig. 4A; 10A-C). The central part of the myocyte contains the nucleus, mitochondria, and rough endoplasmic reticulum (Fig. 10B-C). The contacts between myocytes are gap junctions (Fig. 10B).

\section{Discussion}

General morphology of the buccal apparatus of Clione limacina has been studied by several scientists (Morton, 1958; Lalli, 1970; Yamazaki, Kuwahara, 2017; Norekian et al.,

\footnotetext{
Abbreviations: bc — buccal cone; D — dorsal side; dlm — dorsal longitudinal muscles; oe — esophagus; $r$ — radula; rc — radular bolsters; rlm — radular longitudinal muscles (retractors); rs — radular sac; V — ventral side; vam — bolster ventral approximator muscle; vtm — ventral transversal muscles.

Рис. 3. Трехмерная реконструкция радулярного аппарата Clione limacina. A - общий вид головы с радулой и буккальными конусами; В - радулярный аппарат повернут на $90^{\circ}$ против часовой стрелки, как в реконструкциях C-F; C - вид сбоку передней части радулярного аппарата, радула зелёная полупрозрачная, валики одонтофора коричневые, мышцы зелёные и синие; D - вид сбоку на радулярный аппарат, валики одонтофора коричневые полупрозрачные, поперечные верхние мышцы синие полупрозрачные. Радулярные ретракторы расположены под радулярным мешком. Е радулярный аппарат, вид сбоку. Поперечные вентральные мышцы (мышцы вентрального аппроксиматора) соединяют валики в основании и дорсальную мускулатуру над радулярным мешком; $\mathrm{F}$ - вид сзади на радулярный аппарат без стенки радулярного мешка.

Обозначения: bc - буккальный конус; D - дорсальная сторона; dlm - дорсальная продольная мускулатура; ое - пищевод; r — радула; rlm — радулярная продольная мускулатура (ретракторы); rs — радулярный мешок; $\mathrm{V}$ - вентральная сторона; vam — вентральная аппроксиматор радулярного валика; vtm - вентральная трансверсальная мускулатура.
} 

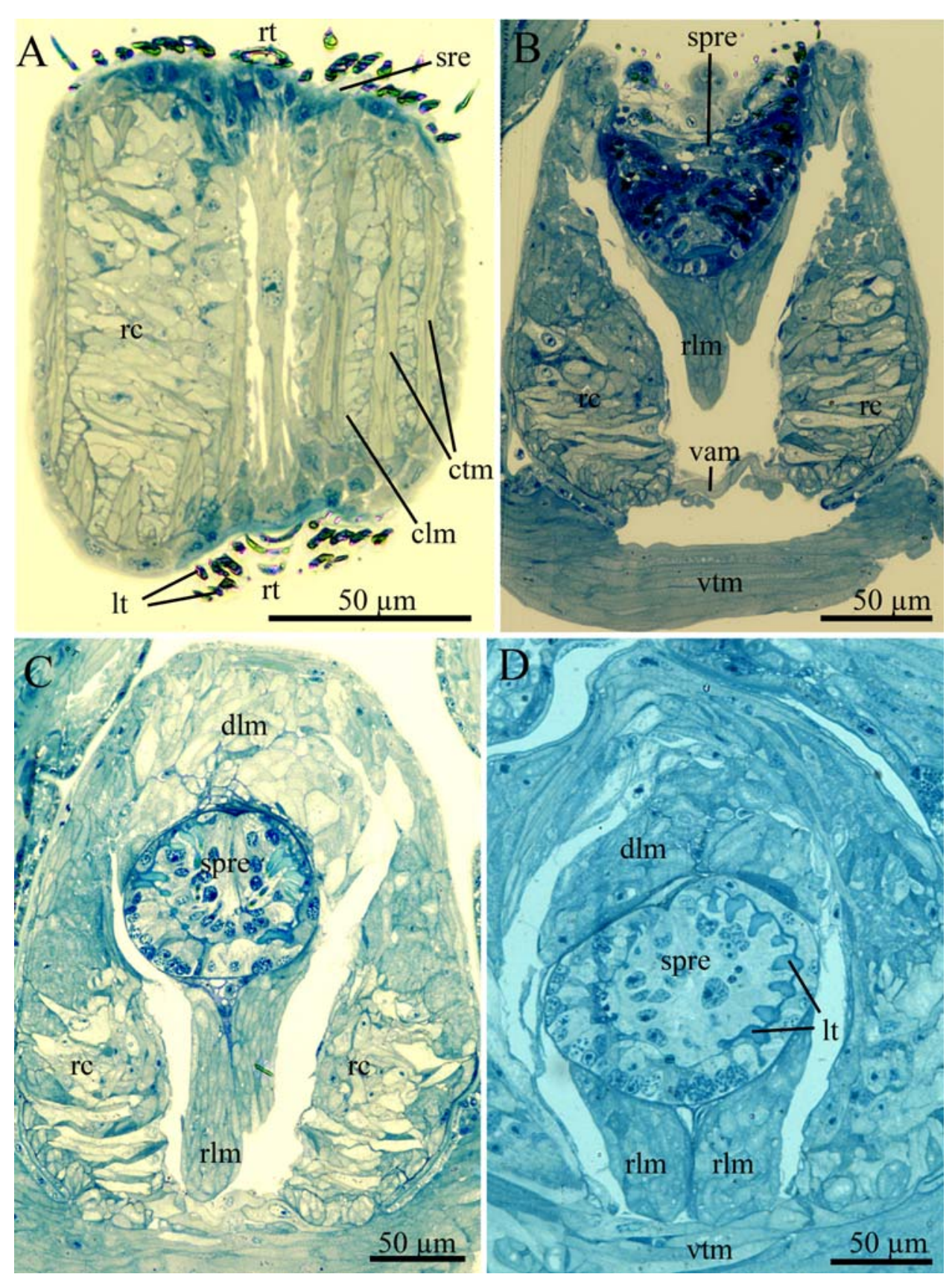

Fig. 4. Histology of the radular apparatus of Clione limacina. A - transversal section through the working zone of the radula. Radular bolsters consist of the muscles without cartilaginous tissue; B - transverse section through the beginning of the radular sac. Pair of the longitudinal muscles are attached to the radula. The ventral approximator is connected to the base of the bolsters; $\mathrm{C}$ - transversal section through the middle region of the radular sac. The teeth are located on the perimeter of the sac; D - transverse section through the formation zone of the radula. Radular sac is immersed in the muscles.

Abbreviations: $\mathrm{clm}$ - bolsters longitudinal muscles; $\mathrm{ctm}$ - bolsters transversal muscles; dlm — dorsal longitudinal muscles; lt — lateral teeth; rc — radular bolsters; rlm — radular longitudinal muscles (retractors); rt — rachidial tooth; 

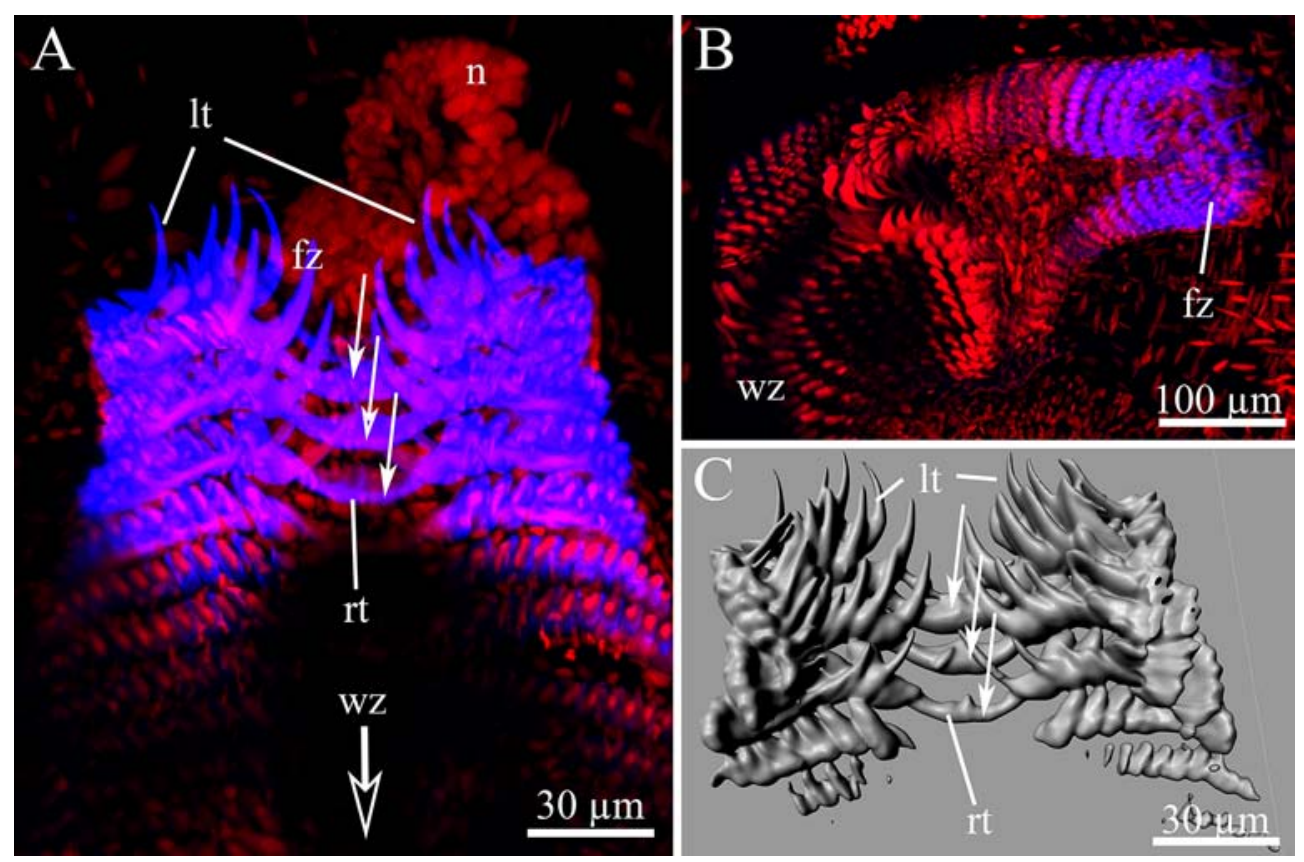

Fig. 5. Chemical composition of the newly formed teeth of Clione limacina. cLSM photos and 3D reconstructions based on these data. Calcofluor white (cfw) (blue color) marks the teeth in maturation zone; nuclei are red (propidium iodide). A - formation zone, the third-fourth newly formed rows of teeth are well detected by cfw (arrows). B - general view of the radula. The matured teeth are emitting in red under 405 $\mathrm{nm}$ wavelengths laser. $\mathrm{C}-3 \mathrm{D}$ reconstruction of the newly formed teeth (arrows), view from above. The radular membrane is not detected by cfw.

Abbreviations: $\mathrm{fz}$ - formation zone of the radula; $1 \mathrm{lt}$ - lateral teeth; $\mathrm{n}$ - nucleus; $\mathrm{rt}$ - rachidial tooth; $\mathrm{wz}$ working zone of the radula.

Рис. 5. Химический состав новых зубов Clione limacina. Фотографии, полученные с помощью конфокального лазерного сканирующего микроскопа, и трехмерные реконструкции на основе этих данных. Зубы в зоне созревания окрашены calcofluor white (cfw) (синий цвет); ядра окрашены йодидом пропидия (красный). A - зона формирования радулы, cfw детектирует три-четыре ряда новых зубов, которые обозначены стрелками. В - общий вид радулы. Зрелые зубы автофлуоресцируют красным при возбуждении лазером с длиной волны 405 нм. С - трехмерная реконструкция новых зубов, вид сверху. Радулярная мембрана не окрашивается cfw.

Обозначения: $\mathrm{fz}$ — зона формирования радулы; $\mathrm{lt}$ — латеральные зубы; $\mathrm{n}$ - ядро; $\mathrm{rt}$ — центральный зуб; wz рабочая зона радулы.

spre — supraradular epithelium; sre — subradular epithelium; vam — bolster ventral approximator muscle; vtm — ventral transversal muscles.

Рис. 4. Гистология радулярного аппарата Clione limacina. A — поперечный срез через рабочую зону радулы. Радулярные валики состоят из мышц без хрящевой ткани; Б - поперечный срез через зону формирования радулы. Радулярная мускулатура состоит из пары продольных мышц, прикрепляющихся к радуле, вентрального аппроксиматора, соединенного с основанием радулярных валиков; В поперечный разрез через среднюю часть радулярного мешка. Зубы расположены по внутреннему периметру мешка; D - поперечный разрез через зону формирования радулы.

Обозначения: clm - продольные мышечные волокна радулярного валика; ctm - трансверсальные мышечные волокна радулярного валика; dlm - дорсальная продольная мускулатура; lt — латеральные зубы; rс радулярный валик; rlm — радулярная продольная мускулатура (ретракторы); rt — центральный зуб; spre супрарадулярный эпителий; sre - субрадулярный эпителий; vam - вентральная аппроксиматор радулярного валика; vtm - вентральная трансверсальная мускулатура. 

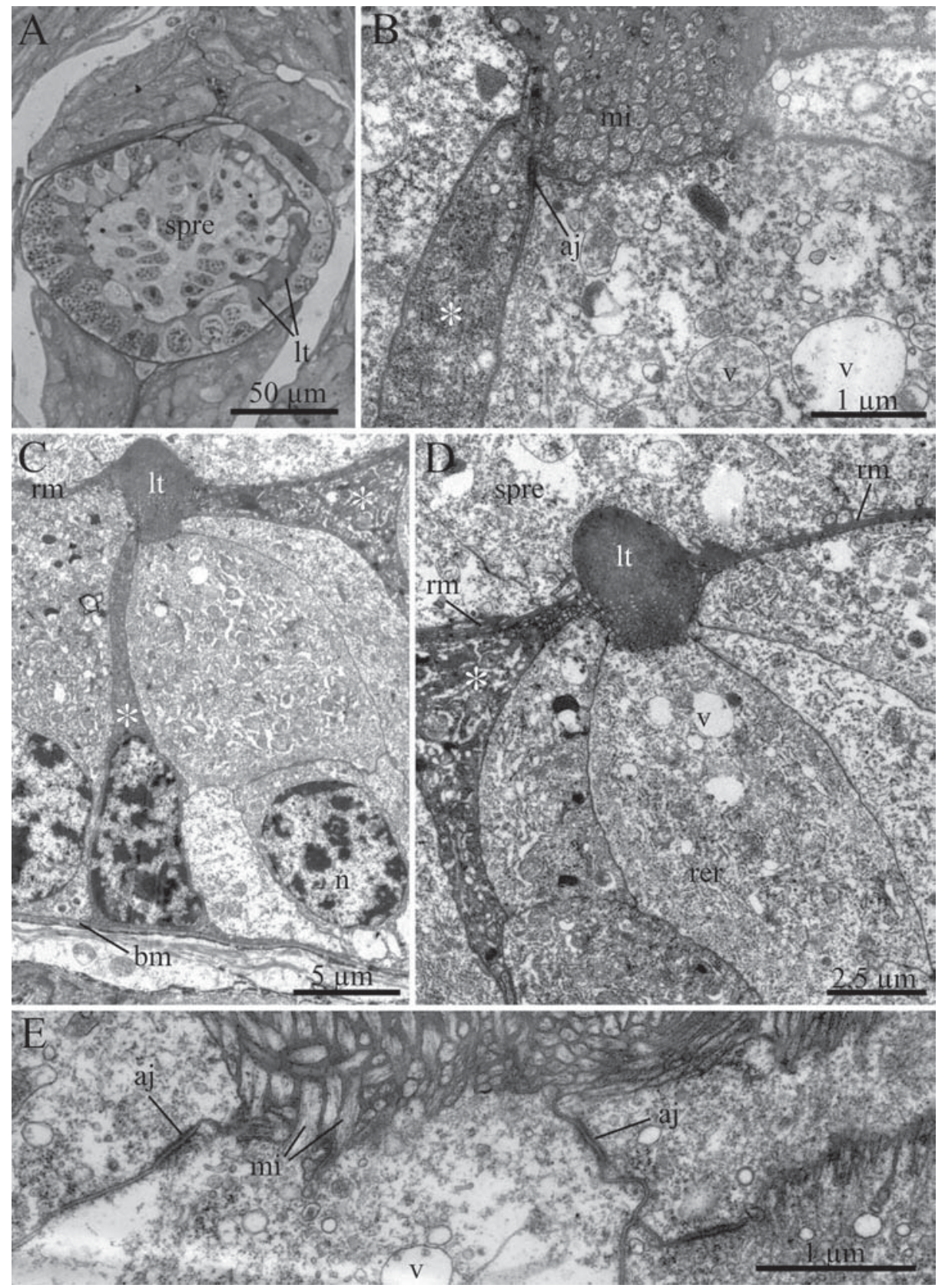

Fig. 6. Ultrastructure of the radular formation zone of Clione limacina, transmission electron microscopy (TEM), transverse section. A - general view of the formation zone. Teeth are located on the perimeter of the radular sac. The fold of supraradular epithelium fills up the inner space of the radular sac; B - apical part of the odontoblasts with microvilli protruding into the new tooth. $\mathrm{C}$ - odontoblasts with electrontransparent cytoplasm; D - apical part of the odontoblasts. One tooth is formed by several cells; E connections between odontoblasts and newly formed tooth. Asterisks label the cells possibly with apoptotic processes.

Abbreviations: aj — adherens junctions; bm — basal membrane; lt — lateral teeth; mi — microvilli; $\mathrm{n}$ - nucleus; rer endoplasmic reticulum; rm — radular membrane; spre — supraradular epithelium; $\mathrm{v}$ - vacuoles. 
2019). However, the application of the $3 \mathrm{D}$ reconstructions, based on semi-thin sections, allows us to clarify some features of the buccal apparatus. The radula and hook sacs are connected by the muscular system. Three groups of muscles associated with the radula have been described earlier: 1) protractor radular muscles; 2) radular retractors; 3 ) ventral transversal muscles, connecting hook sacs and radular sac (La1li, 1970). Here we describe two additional groups of the radular muscles: 4) dorsal longitudinal radular muscles and 5) bolster ventral approximator muscle, contacting with the bases of the radular bolster. Dorsal longitudinal muscles help radular retractors to retract the radula during its operation, while radular bolster ventral approximator muscle additionally helps the radula stretching on the odontophore in the working zone.

The radula of a majority of Gymnosomata consists of the central tooth, and several (from 2 to 10) hooked lateral teeth (Pruvot-Fol, 1954; van der Spoel, 1976). The number of lateral teeth of two genera (Clione and Cliopsis) increases during maturation (Pruvot-Fol, 1954; van der Spoel, 1976; Angulo-Campillo, AcevesMedina, 2018). The maturation of $C$. limacina radula has been shown to have the following features: the number and size of the lateral teeth increase with the growth of the specimen. Radula of $C$. limacina has been stained by calcofluor white (cfw) that marked, among other, nonpolymerized chitin (Hickey et al., 2004; Connors et al., 2012). Since cfw marked teeth in the maturation zone of the radula (Vortsepneva, Tzetlin, 2019) this confirms that tooth consists of unpolymerized chitin before the mineralization. Nevertheless more studies, including larval development, are necessary for the under- standing of the chemical composition and teeth maturation.

Based on the ultrastructural studies the formation of a radula in gastropods could be characterized by the following criteria: 1) different number of cells synthesizing a single tooth (from single odontoblast, as in Opisthobranchia, to many hundreds of odontoblasts in Patellogastropoda); 2) odontoblasts are grouped according to the number of teeth in transversal row; the shape and size of odontoblasts most probably depend on the number of odontoblasts in one group; 3 ) the type of tooth synthesis varies in different mollusks. Tooth could be formed by apocrine secretion (Patelogastropoda), by microvillar growth (Patelogastropoda and Heteronranchia), or by the secretion of a mixed type (Heteronranchia) (Wiesel, Peters, 1978; Hughes, 1979; Kerth, 1979; Peters, 1979; Mischor, Markel, 1984; Mackenstedt, Märkel, 1987; Mikhlina et al., 2018; Vortsepneva, Tzetlin, 2019; Vortsepneva et al., 2019). As it has been described for other Heterobranchia (Mikhlina et al., 2018), a single tooth of C. limacina is formed by several cells through microvillar secretion. The number of teeth in C. limacina increases during the life of the animal, possibly, due to the odontoblasts position on the inner perimeter of the radular sac. Teeth of other gastropods are formed by ventrally or lateroventrally arranged odontoblasts (Peters, 1979; Mackenstedt, Märkel, 1987; Mischor, Markel, 1984; Mikhlina et al., 2018; Vortsepneva, Tzetlin, 2019).

As radula of Clione limacina have welldefined teeth and radular membrane, two cell types should participate in its synthesis, the odontoblasts and membranoblasts, which, as is typical to other gastropods, should differ from

Рис. 6. Ультраструктура зоны формирования радулы Clione limacina, трансмиссионная электронная микроскопия (ТЭМ), поперечный срез. А - общий вид зоны формирования. Зубы расположены по периметру круглого мешка. Складка супрарадулярного эпителия заполняет внутреннее пространство радулярного мешка; Б - апикальная часть одонтобластов с микроворсинками, пронизывающими новый зуб; C - одонтобласты с электронно-прозрачной цитоплазмой; D — верхушечная часть одонтобластов. Один зуб состоит из нескольких клеток; Е - связи между одонтобластами и новым зубом. Звездочки помечают апоптотические клетки.

Обозначения: ај - адгезивные контакты; bm - базальная мембрана; 1 - латеральные зубы; ті — микровилли; $\mathrm{n}$ - ядро; rer - шероховатый эндоплазматический ретикулюм; rm - радуларная мембрана; spre — супрарадулярный эпителий; v — вакуоль. 

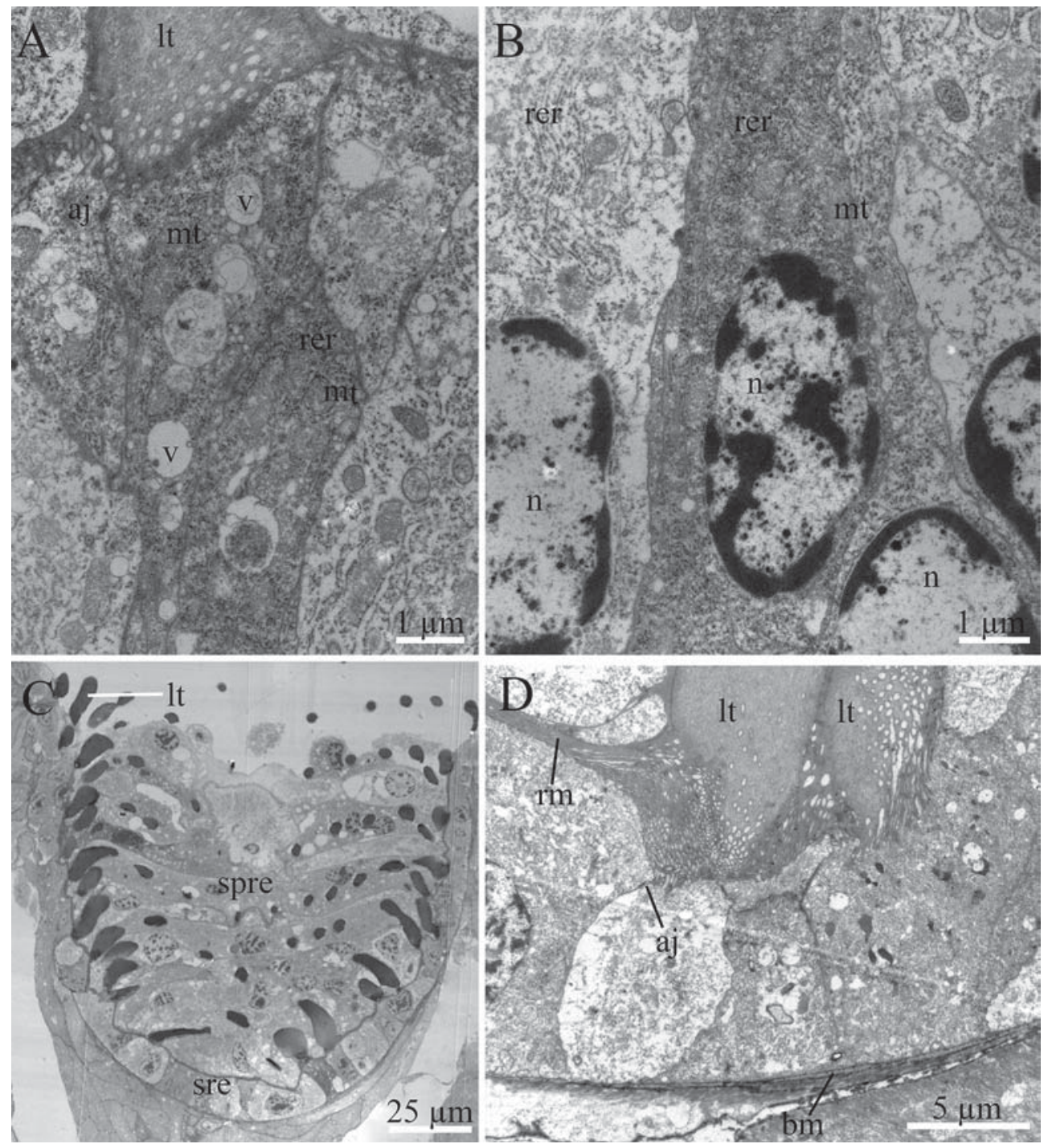

Fig. 7. Ultrastructure of the concomitant epithelium in the radular sac of Clione limacina, transmission electron microscopy, frontal section. A - apical part of the subradular epithelium. The base of the tooth is not homogenous and contains vesicles; B - the middle part of the subradular epithelium with the nucleus; $\mathrm{C}-$ general view of the anterior end of the radular sac. Subradular epithelium consists of square cells; D teeth and radular membrane the same as in fig $\mathrm{C}$.

Abbreviations: aj — adherens junctions; bm — basal membrane; lt — lateral teeth; $\mathrm{mi}$ - microvilli; $\mathrm{mt}$ - mitochondria; $\mathrm{n}$ - nucleus; rer — endoplasmic reticulum; rm — radular membrane; spre — supraradular epithelium; sre — subradular epithelium; $v$ - vacuoles.

Рис. 7. Ультраструктура эпителия радулярного мешка Clione limacina, трансмиссионная электронная микроскопия (ТЭМ), фронтальный срез. А - апикальная часть субрадулярного эпителия. Основание зуба неоднородное с везикулами; Б - средняя часть субрадулярного эпителия с ядром; В - общий вид переднего конца радулярного мешка; D - зубцы и радулярная мембрана.

Обозначения: aj — адгезивные контакты; bm - базальная мембрана; $1 \mathrm{t}$ — латеральные зубы; mi — микровилли; $\mathrm{mt}$ - митохондрия; $\mathrm{n}$ - ядро; rer - шероховатый эндоплазматический ретикулюм; rm - радуларная мембрана; spre - супрарадулярный эпителий; sre — субрадулярный эпителий; v — вакуоль. 


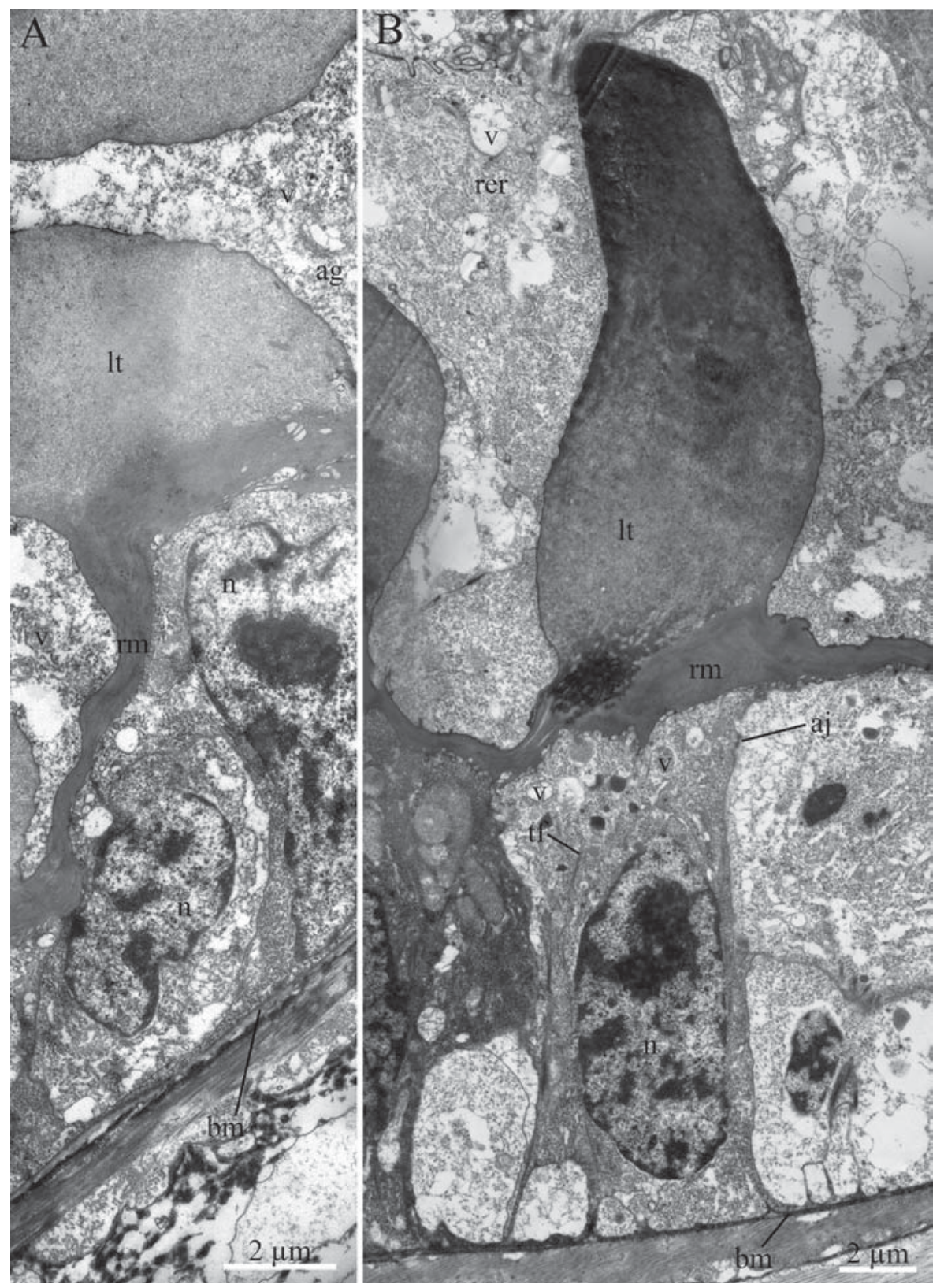

Fig. 8. Matured radular teeth and membrane of Clione limacina, transmission electron microscopy, transverse section. A-B - teeth attached to the membrane. Matured teeth are homogenous and electron-dense as well as the membrane. The cells of subradular epithelium are rectangular with big nuclei and tonofilaments.

Abbreviations: ag — Golgi apparatus; aj — adherens junctions; bm — basal membrane; lt — lateral teeth; $\mathrm{n}$ — nucleus; rer - endoplasmic reticulum; $\mathrm{rm}$ - radular membrane; $\mathrm{v}$ - vacuoles; tf — tonofilaments.

Рис. 8. Зрелые радулярные зубы и мембрана Clione limacina, трансмиссионная электронная микроскопия (ТЭМ), поперечный срез. А-Б - зубы, прикрепленные к мембране. Зрелые зубы гомогенные электронноплотные. Клетки субрадулярного эпителия прямоугольные с большими ядрами и тонофиламентами. Обозначения: ag — аппарат Гольджи; aj — адгезивные контакты; bm - базальная мембрана; $1 \mathrm{t}$ — латеральные зубы; $\mathrm{n}$ - ядро; rer - шероховатый эндоплазматический ретикулюм; rm - радуларная мембрана; $\mathrm{tf}-$ тонофиламенты; $\mathrm{v}$ - вакуоль. 

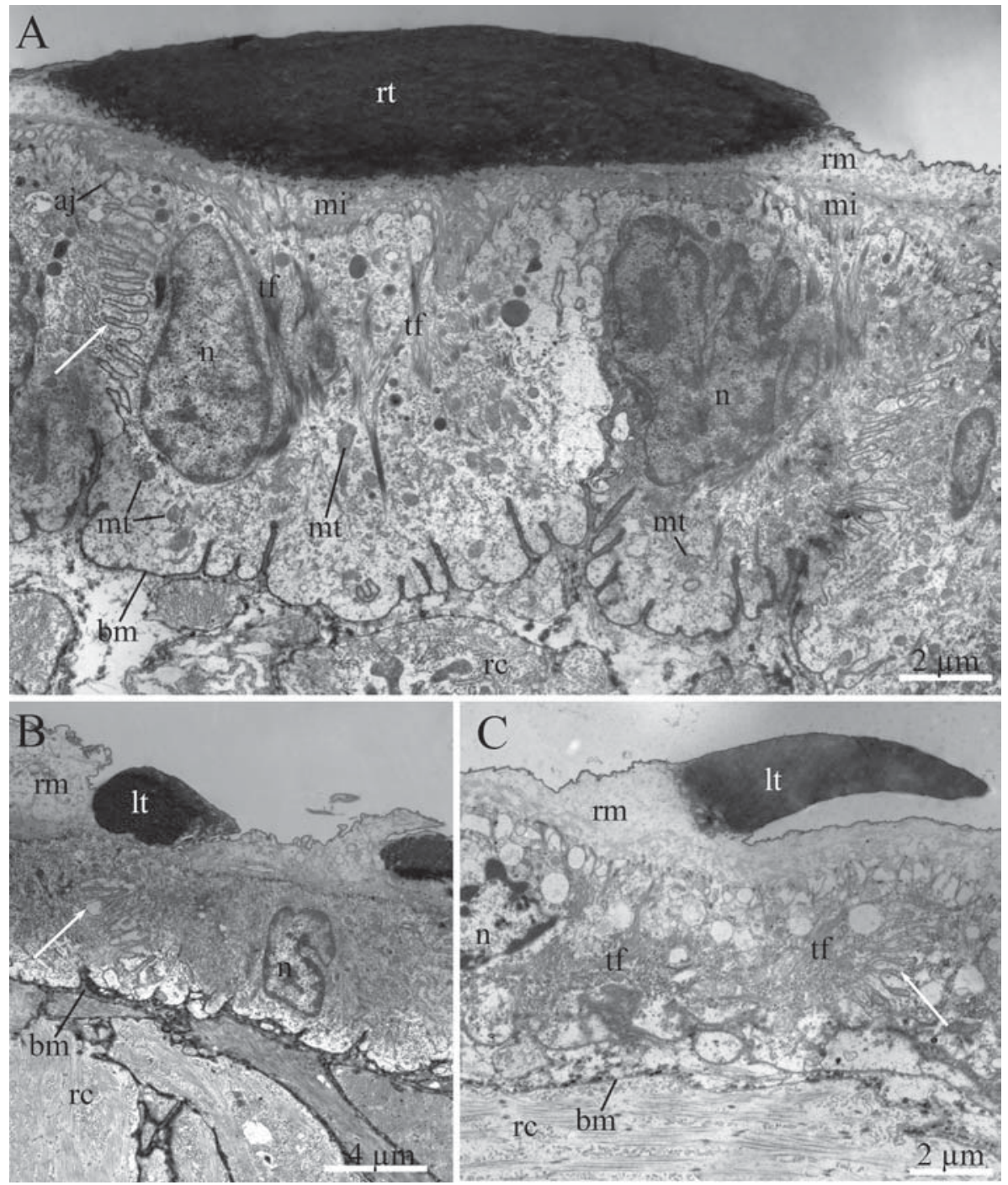

Fig. 9. Ultrastructure of the working zone of Clione limacina, transmission electron microscopy. A transverse section through the subradular epithelium and rachidial tooth (central plate). Subradular epithelium contains a lot of bundles of tonofilaments. The contacts between the cells are adherens junctions and cytoplasmic interdigitations (arrows). Radular membrane is electron-transparent; B - a longitudinal section through the lateral teeth, muscles of radular bolster are connected to the subradular epithelium. C longitudinal section through the lateral tooth.

Abbreviations: aj — adherens junctions; bm — basal membrane; lt — lateral teeth; mi — microvilli; $\mathrm{mt}$ - mitochondria; $\mathrm{n}$ - nucleus; rc - radular bolsters; $\mathrm{rm}$ - radular membrane; $\mathrm{rt}$ - rachidial tooth; $\mathrm{tf}$ - tonofilaments.

Рис. 9. Ультраструктура рабочей зоны Clione limacina, трансмиссионная электронная микроскопия (ТЭМ). А - поперечный срез через субрадулярный эпителий и центральный зуб. Субрадулярный эпителий содержит пучки тонофиламентов. Контакты между клетками обеспечиваются плотными контактами и цитоплазматическими инвагинациями (стрелки); Б - продольный срез через латеральные зубы, мышцы радулярного валика соединены с субрадулярным эпителием; С - продольный срез через латеральный зуб.

Обозначения: aj — адгезивные контакты; bm — базальная мембрана; lt — латеральные зубы; mi — микровилли; $\mathrm{mt}$ - митохондрия; n — ядро; rc — радулярный валик; rm — радуларная мембрана; $\mathrm{rt}$ - центральный зуб; $\mathrm{tf}$ тонофиламенты. 

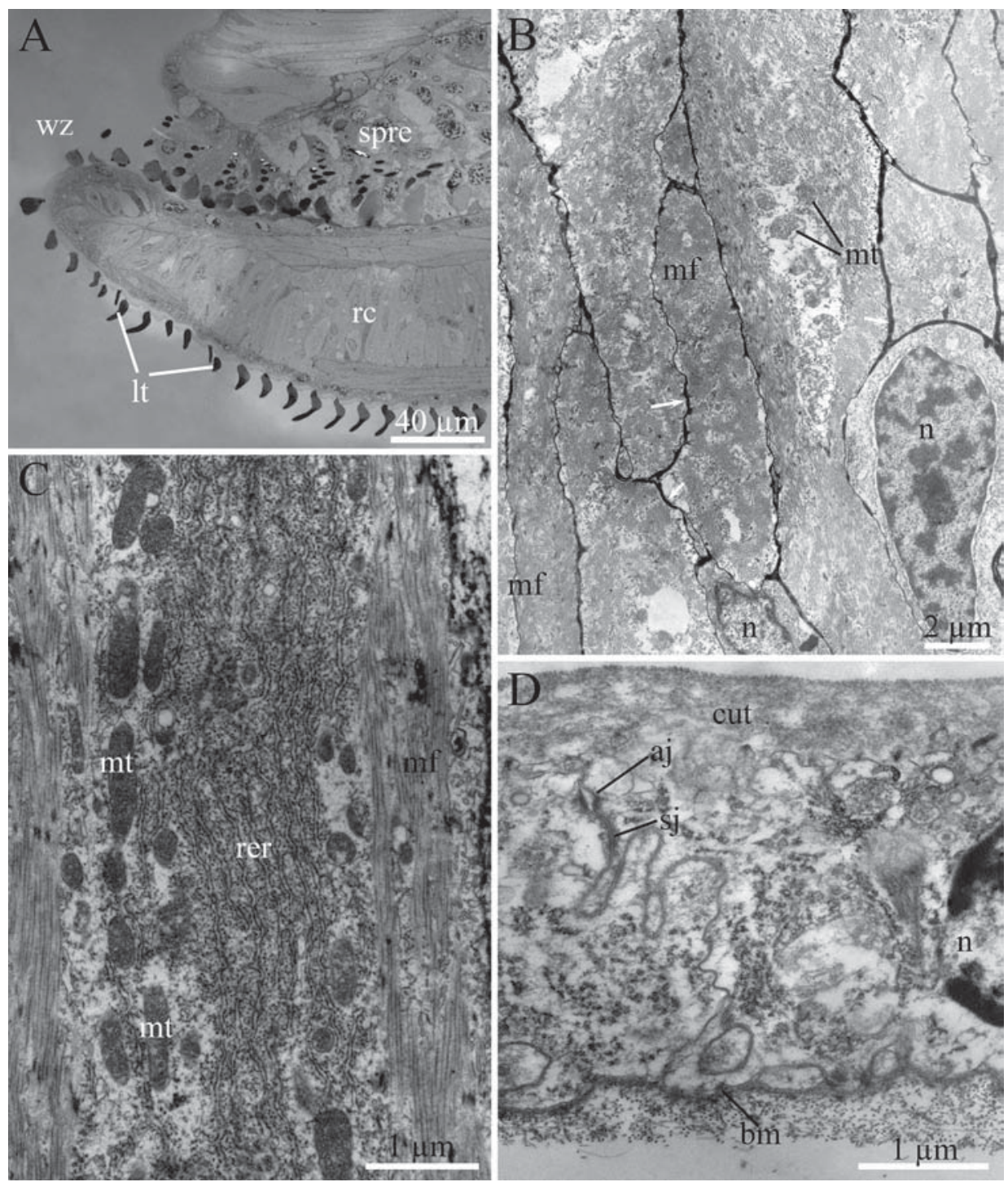

Fig. 10. Ultrastructure of the radular bolsters of Clione limacina, transmission electron microscopy. A longitudinal section through the working zone of the radula with bolster; B - ultrastructure of the radular bolster which consists of the muscles; C - magnified muscle fibers of the bolster, Gap junctions are shown by arrows; D - longitudinal section through the buccal epithelium after degradation zone. The cuticle is amorphous.

Abbreviations: aj — adherens junctions; bm — basal membrane; cut — cuticle; lt — lateral teeth; $\mathrm{mf}$ - myofilaments; $\mathrm{mt}$ - mitochondria; $\mathrm{n}$ — nucleus; $\mathrm{rc}$ - radular bolsters; rer — endoplasmic reticulum; $\mathrm{rt}$ — rachidial tooth; sj — septate junctions; spre - supraradular epithelium; tf — tonofilaments; wz — working zone of the radula.

Рис. 10. Ультраструктура радулярных валиков Clione limacina, трансмиссионная электронная микроскопия (ТЭМ). А - продольный срез рабочей зоны радулы с валиком; Б - ультраструктура радулярного валика, который состоит из мышц; С - увеличенные мышечные волокна валика, стрелками обозначены контакты; D - продольный срез через буккальный эпителий с аморфной кутикулой после зоны деградации.

Обозначения: aj — адгезивные контакты; bm - базальная мембрана; cut — кутикула; lt — латеральные зубы; $\mathrm{mf}$ - миофиламенты; $\mathrm{mt}$ — митохондрия; $\mathrm{n}$ - ядро; $\mathrm{rer}$ - шероховатый эндоплазматический ретикулюм; $\mathrm{rc}-$ радулярный валик; $\mathrm{rm}$ - радуларная мембрана; $\mathrm{rt}$ — центральный зуб; tf — тонофиламенты. 
each other by position, morphology, and function (Peters, 1979; Mischor, Markel, 1984; Mackenstedt, Märkel, 1987; Mikhlina et al., 2018; Vortsepneva, Tzetlin, 2019). However, in C. limacina we were unable to distinguish these cell types at the ultrastructural level, but suggest to discriminate them, according to their different functions. The cells of subradular epithelium of $C$. limacina in the maturation zone are similar to odontoblasts. In other gastropods, various functional modifications of the subradular epithelium have been described. For example, Conus pulicarius is characterized by concomitant epithelium with thick bundles of tonofilaments, which probably participate in rolling of forming teeth (Vortsepneva et al., 2019).

Radular membrane of Clione limacina is very thin and electron-dense in the formation and maturation zones but electron-transparent in the working and degradation zones, differing in that from the radular membrane of other gastropods (Mischor, Markel, 1984; Mackenstedt, Märkel, 1987; Mikhlina et al., 2018). Additional membrane outgrowth (alary processes) in the working zone and subradular membrane are absent. The function of the subradular membrane is facilitating the movement of the radula relative to radular cartilages, and it is well developed in the gastropods with the scraping feed type (Vortsepneva, Tzetlin, 2019). The lack of a subradular membrane in C. limacina probably indicates the limited movement of the radula relative to the odontophore. The subradular epithelium of $C$. limacina in the working zone is reinforced by additional interdigitating connections between the cells and bundles of tonofilaments. The myofibers of the radular bolster are attached to the subradular epithelium. Radula bolster consists of the muscular fibers without cartilaginous tissue and belong to the type of a support structure, which is characteristic of all Heterobranchia (Katsuno, Sasaki, 2008). The bolsters are connected with ventral approximator muscles what is characteristic to other Heterobranchia (Katsuno, Sasaki, 2008).

\section{Acknowledgments}

I am grateful to Dr. Andrey Lavrov and Dr. Maria Schreider for the help with English and to
Prof. Alexander Tzetlin for the fruitful discussion. I express my gratitude to G. Davidovich and A. Bogdanov and Electron Microscopy Laboratory of the Shared Facilities Center of Lomonosov Moscow State University sponsored by the RF Ministry of Education and Science and Research. I thanks to S. Mitelev and G. Bykov (I.D. Papanin Institute for the biology of inland waters, Russian Academy of Sciences) for the help with electron microscopy. I am grateful to reviewers and redactors for the corrections which improved the manuscript. The light microscopy study was conducted using equipment of the Center of microscopy WSBS MSU. This work was supported by Moscow State University Grant for Leading Scientific Schools "Depository of the Living Systems" in the frame of the MSU Development Program. The study was supported by the Russian Foundation for Basic Research grants \#18-05-60158 and \#19-04-00501.

\section{References}

Angulo-Campillo O., Aceves-Medina G. 2018. Two new species of gymnosomatous pteropods from the Gulf of California (Gymnosomata: Pneumodermatidae) // Hidrobiologica. Vol.28. No.3. P.231-237.

Arshavsky Y.I., Deliagina T.G., Orlovsky G.N., Panchin Yu.V. 1989. Control of feeding movements in the pteropod mollusk, Clione limacina // Exp. Brain Res. Vol.78. No.2. P.387-397.

Arshavsky Y.I., Deliagina T.G., Gelfand I.M., Orlovsky G.N., Panchin Yu.V., Pavlova G.A., Popova L.B. 1990. Neural control of heart beat in the pteropod mollusc Clione limacina: coordination of circulatory and locomotor systems // J. Exp. Biol. Vol.148. P.461475.

Conover R.J., Lalli C.M. 1974. Feeding and growth in Clione limacina (Phipps), a pteropod mollusc. II. Assimilation, metabolism, and growth efficiency // J. Exp. Mar. Bio. Ecol. Vol.16. No.2. P.131-154.

Connors M.J., Ehrlich H., Hog M., Godeffroy C., Araya S., Kallai I., Gazit D., Boyce M., Ortiz C. 2012. Threedimensional structure of the shell plate assembly of the chiton Tonicella marmorea and its biomechanical consequences // J. Struct. Biol. Vol.177. P.314-328.

Corse E., Rampal J., Cuoc C., Pech N., Perez Y., Gilles A. 2013. Phylogenetic analysis of Thecosomata Blainville, 1824 (Holoplanktonic Opisthobranchia) using morphological and molecular data // PLoS One. Vol.8. No.4.

Dinapoli A., Klussmann-Kolb A. 2010. The long way to diversity - phylogeny and evolution of the Hetero- 
branchia (Mollusca: Gastropoda) // Mol. Phylogenet. Evol. Vol.55. No.1. P.60-76.

Hermans C.O., Satterlie R.A. 1992. Fast-strike feeding behavior in a pteropod mollusk, Clione limacina Phipps // Biol. Bull. Vol.182. No.1. P.1-7.

Hickey P.C., Swift S.R., Roca M.G., Read N.D. 2004. Live-cell imaging of filamentous fungi using vital fluorescent dyes and confocal microscopy // Methods Microbiol. Vol.34. P.63-87.

Hopkins T.L. 1985. Food web of an Antarctic midwater ecosystem // Mar. Biol. Vol.89. No.2. P.197-212.

Huang Z., Satterlie R.A. 1989. Smooth muscle fiber types and a novel pattern of thick filaments in the wing of the pteropod mollusc Clione limacina // Cell Tissue Res. Vol.257. P.405-414.

Hughes R. 1979. Ultrastructure of the buccal mass in juvenile Coryphella salmonacea (Gastropoda: Nudibranchia) // J. Molluscan Stud. Vol.45. P.289-295.

Katsuno S., Sasaki T. 2008. Comparative histology of radula-supporting structures in Gastropoda // Malacologia. Vol.50. No.1. P.13-56.

Kattner G., Hagen W., Greave M., Alberts C. 1998. Exceptional lipids and fatty acids in the pteropod Clione limacina (Gastropoda) from both polar oceans // Mar. Chem. Vol.61. No.3-4. P.219-228.

Kerth K. 1979. Electron microscopic studies on radular tooth formation in the snails Helix pomatia L. and Limax flavus L. (Pulmonata, Stylommatophora) // Cell Tissue Res. Vol.203. No.2. P.283-289.

Klussmann-Kolb A., Dinapoli A. 2006. Systematic position of the pelagic Thecosomata and Gymnosomata within Opisthobranchia (Mollusca, Gastropoda) Revival of the Pteropoda // J. Zool. Syst. Evol. Res. Vol.44. No.2. P.118-129.

Lalli C.M. 1970. Structure and function of the buccal apparatus of Clione limacina (Phipps) with a review of feeding in gymnosomatous pteropod // J. Exp. Mar. Bio. Ecol. Vol.4. No.2. P.101-118.

Lalli C.M., Gilmer R.W. 1989. Pelagic snails: the biology of holoplanktonic gastropod mollusks. Stanford University Press. 276 p.

Mackenstedt U., Märkel K. 1987. Experimental and comparative morphology of radula renewal in pulmonates (Mollusca, Gastropoda) // Zoomorphology. Vol.107. No.4. P.209-239.

Mikhlina A., Tzetlin A., Vortsepneva E. 2018. Renewal mechanisms of buccal armature in Flabellina verrucosa (Nudibranchia: Aeolidida: Flabellinidae) // Zoomorphology. Vol.137. No.1. P.31-50.

Mischor B., Markel K. 1984. Histology and regeneration of the radula of Pomacea bridgesi (Gastropoda, Prosobranchia) // Zoomorphology. Vol.104. P.42-66.

Morton J.E. 1958. Observations on the gymnosomatous pteropod Clione limacina (Phipps) // J. Mar. Biol. Assoc. United Kingdom. Vol.37. No.2. P.287-297.

Norekian T.P., Hermans C.O., Satterlie R.A. 2019. Organization of buccal cone musculature in the pteropod mollusc Clione limacina // Biol. Bull. Vol.237. No.1. P.36-47.
Norekian T.P., Satterlie R.A. 1997. Cholinergic activation of startle motoneurons by a pair of cerebral interneurons in the pteropod mollusk Clione limacina // J. Neurophysiol. Vol.77. No.1. P.281-288.

Peters W. 1979. Basal bodies in the odontoblasts of the limpet, Patella coerulea L . (Gastropoda) // Cell Tissue Res. Vol.202. P.295-301.

Pruvot-Fol A. 1954. Mollusques Opisthobranches // Faune de France. No.58. Paris. 460 p.

Ruthensteiner B., Heß M. 2008. Embedding 3D models of biological specimens in PDF publications // Microsc. Res. Tech. Vol.71. P.778-786.

Satterlie R.A. 1991. Electrophysiology of swim musculature in the pteropod mollusc Clione limacina // J. Exp. Biol. Vol.301. P.285-301.

Thollesson M. 1999. Phylogenetic analysis of Euthyneura (Gastropoda) by means of the 16S rRNA gene: use of a "fast' gene for "higher-level' phylogenies // Proc. R. Soc. London. Ser. B Biol. Sci. Vol.266. No.B. P.7583.

van der Spoel S. 1976. Pseudothecosomata, Gymnosomata and Heteropoda (Gastropoda). Utreht: Bohn, Scheltema and Holkema. 484 p.

Vortsepneva E., Tzetlin A. 2019. General morphology and ultrastructure of the radula of Testudinalia testudinalis (O. F. Müller, 1776) // J. Morphol. Vol.280. P.17141733.

Vortsepneva E., Tzetlin A., Kantor Y. 2019. First ultrastructural study of the formation of the hypodermic radula teeth of Conus (Neogastropoda: Conidae) // J. Molluscan Stud. Vol.85. P.184-196.

Vortsepneva E.V., Tzetlin A.B. 2014. [New data on the fine structure of hooks in Clione limacina (Gastropo$\mathrm{da}$, Opistobranchia) and diversity of the jaw apparatus in gastropods] // Zool. Zhurnal. Vol.93. No.3. P.466478 [in Russian].

Wiesel R., Peters W. 1978. Licht- und elektronenmikroskopische Untersuchungen am Radulakomplex und zur Radulabildung von Biomphalaria glabrata Say (= Australorbis gl.) (Gastropoda, Basommatophora) // Zoomorphologie. Bd.98. S.73-92.

Yamazaki T., Kuwahara T. 2017. A new species of Clione distinguished from sympatric C. limacina (Gastropoda: Gymnosomata) in the southern Okhotsk Sea, Japan, with remarks on the taxonomy of the genus // J. Molluscan Stud. Vol.83. No.1. P.19-26.

Yamazaki T., Kuwahara T., Takahashi K.T. 2018. Genetic differences in spatially and temporally isolated populations: winter and wpring wopulations of welagic mollusk Clione (Mollusk: Gymnosomata), Southern Okhotsk Sea, Japan // Thalass. An Int. J. Mar. Sci. Vol.34. No.2. P.447-458.

Zapata F., Wilson N.G., Howison M., Andrade S.C.S, Jörger K.M., Schrödl M., Goetz F.E., Giribet G., Dunn C.W. 2014. Phylogenomic analyses of deep gastropod relationships reject Orthogastropoda// Proc. R. Soc. B Biol. Sci. Vol.281. No.1794.

Responsible editors V.N. Ivanenko, E.N. Temereva 